\title{
THERMAL ANALYSIS OF WATER COOLED CHARGE AIR COOLER IN TURBO CHARGED DIESEL ENGINE
}

\author{
J.N. Devi Sankar', P.S.Kis hore ${ }^{2}$ \\ ${ }^{I}$ M.E. (Heat transfer in Energy Systems) Student, Department of Mechanical Engineering, College of Engineering (A), \\ Andhra University, Visakhapatnam, Andhra Pradesh, India \\ ${ }^{2}$ Professor, Department of Mechanical Engineering, College of Engineering (A), Andhra University, Visakhapatnam, \\ Andhra Pradesh, India
}

\begin{abstract}
Air-cooled and water-cooled charge air coolers are used as applications in automobiles. The cooling media include engine's coolant, ambient air or any other external coolant source. Charge air cooler with offset strip fin geometry is chosen on both hot and cold sides with fin thickness $0.15 \mathrm{~mm}$, length $3.2 \mathrm{~mm}$, height $5.2 \mathrm{~mm}$ and frequency of 18 fins per inch. The flow rate on hot side is taken as $0.3 \mathrm{~kg} / \mathrm{s}$ and cold side as $2 \mathrm{~kg} / \mathrm{s}$ for air-cooled charge air cooler and for water-cooled charge air cooler on hot side it is $0.3 \mathrm{~kg} / \mathrm{s}$ and cold side is $0.265 \mathrm{~kg} / \mathrm{s}$ with inlet temperature on hot side $160^{\circ} \mathrm{C}$ and cold side $40{ }^{\circ} \mathrm{C}$. With the above conditions, performance evaluation is done on both charge air coolers. Having found water-cooled charge air cooler is having higher effectiveness than air-cooled type, performance evaluation is carried out on water-cooled charge air cooler with varying mass flow rates on hot side from 0.1 to $0.6 \mathrm{~kg} / \mathrm{s}$ and keeping cold fluid rate constant at $0.265 \mathrm{~kg} / \mathrm{s}$ and the outputs obtained are Colbum-j factor, Fanning friction factor, heat transfer coefficient, overall heat transfer coefficient and effectiveness of heat exchanger. From the obtained results, graphs are drawn to assess the performance of the water charge air cooler.
\end{abstract}

Keywords: Charge Air Cooler, Plate Fin Heat Exchanger, Colburn-J Factor, Heat Transfer Coefficient, Fanning Friction Factor, Effectiveness

\section{INTRODUCTION}

Different types of heat exchangers are used in aerospace and automobiles as charge air coolers (CAC), radiators, oil coolers, heater cores, air conditioning machines (ACM), etc. The present work is concentrated on charge air cooler. The main goal of charge air cooler is to decrease the temperature of in let air entering into the cylinder. In this work, thermal and heat transfer analysis is carried out on an air cooler treating it to be a plate fin heat exchanger. To install this in aero or automobile application, space is a major constraint. So the exchanger chosen should be compact enough. These are characterized by high heat transfer surface area per unit volume.

Several researchers discussed performance of different types of heat exchangers used for different purposes and developed correlations both numerically and experimentally. Shah and Sekulic [1] pointed out that compact heat exchangers are taken to have large surface area/volume ratios. Plate fin exchanger is used for various applications which use plain, wavy, offset, perforated, pin and louvered fins. Manglik and Bergles [2] in their paper discussed the effect of fin geometry on heat transfer and pressure drop correlations. The results are found to be in close agreement with experimental data got by Kays and London [3]. Zhang et al. [4] in their article gave the increase in heat transfer in parallel plate fin heat exchangers. This includes inline and staggered array arrangements of offset fins taking fin thickness. Dejong et al. [5] in their paper studied flow and heat transfer both experimentally and numerically to evaluate skin friction coefficient and Nusselt number on off strip channel. Bhowmik and Lee [6] in their study derived pressure drop and heat transfer effects on offset strip fin heat exchanger using a three dimensional model. Friction factor and Colburn $\mathrm{j}$ - factors are arrived for both laminar and turbulent flow regimes. $\mathrm{Hu}$ and Herold [7] discussed experimentally the Prandtl number effect on heat transfer and pressure drop for offset strip fin array. Devi sankar [8] in his thesis carried out performance analysis of charge air cooler with offset strip fin geometry in turbo charged diesel engine and studied the effect of mass flow rates of air on Colburn-j factor, friction factor, heat transfer coefficient and effectiveness of water cooled charge air cooler. In his work, a charge air cooler in turbo charged diesel engine is chosen as a cross flow heat exchanger where charge air is cooled by coolant (water).

\section{DESCRIPTION AND WORKING OF CHARGE} AIR COOLER IN TURBOCHARGED DIESEL ENGINE

A turbocharger is a turbine-driven forced induction device that increases internal combustion engine efficiency and power output by forcing extra air into the cylinder. The turbocharger has two major components i.e. compressor and turbine. Compressor is driven by turbine on which the hot gases from exhaust manifold strikes the turbine blade and 
expands to produce some work. Compressor takes air from outside through an air cleaner and compresses it.

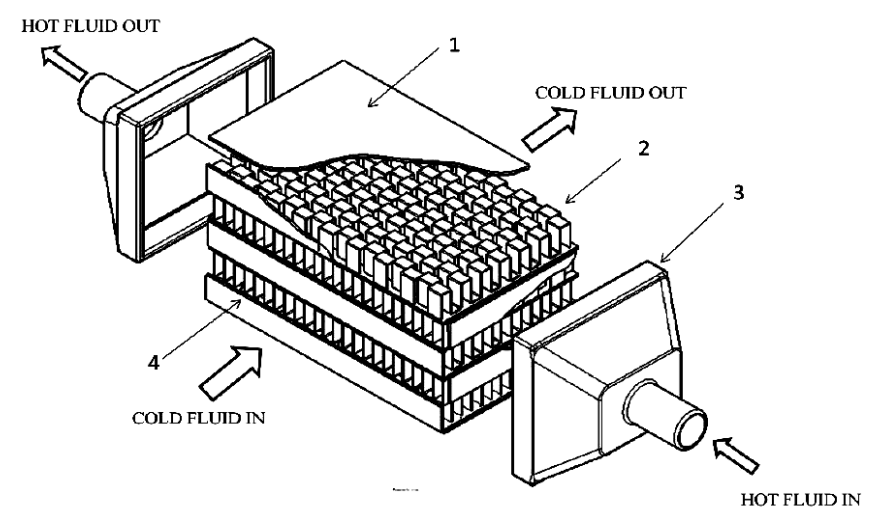

Fig-1: Charge air cooler core geo metry

1) Parting sheet 2) Offset fin 3) Header 4) Side bar

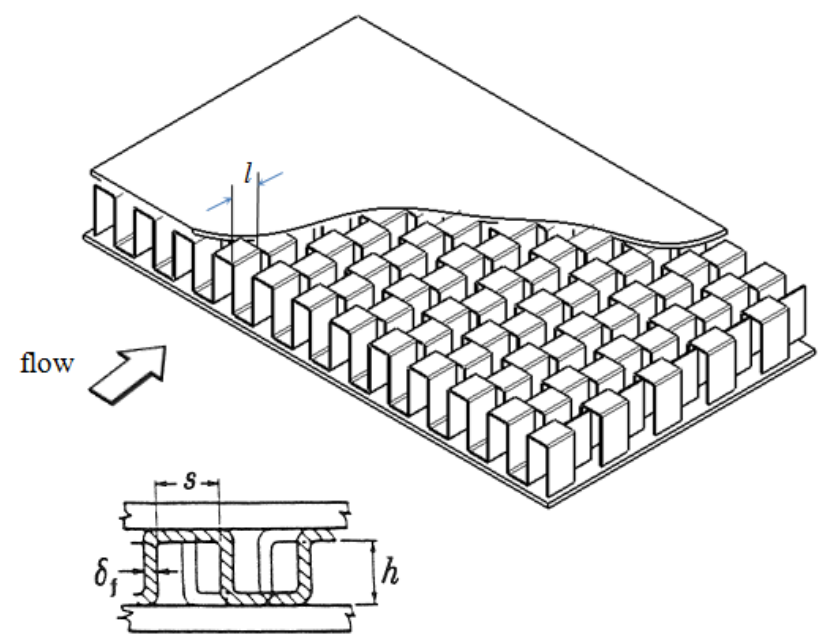

Fig -2: Offset strip fin

Fig.1 shows charge air cooler (CAC) with cross flow arrangement. The main components of the CAC are parting sheets, fin, header and side bar. All the components are held together to form a plate fin heat exchanger. Fig. 2 shows offset strip fin geometry put on both sides of the heat exchanger.

\subsection{AIR TO AIR INTERCOOLING}

In Fig. 3 charge air cooler is put before intake manifold and after compressor. The major components in the system are turbocharger, charge air cooler, engine intake and exhaust manifolds. The ambient air is sucked into the compressor through an air filter, where it is compressed to high temperature. Compressed air leaves the compressor and enters into charge air cooler with high temperature, which rejects its heat to the ambient air and cools down. The cooled charge from the CAC enters into the intake manifold. After completion of cycle, exhaust gases from engine enter into exhaust manifold before it leaves to the atmosphere. Energy of the exhaust gases were used to run the turbine.

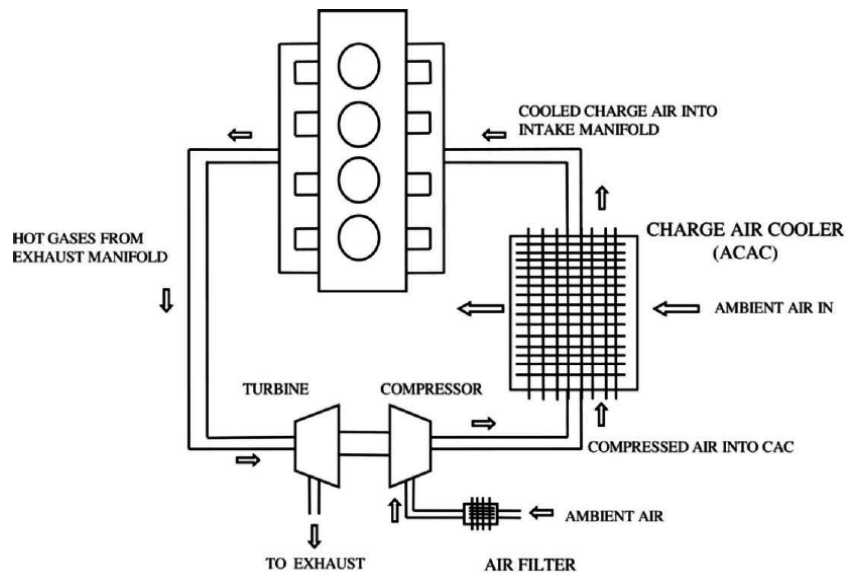

Fig-3: Air to Air charge air cooler circuit

\subsection{AIR TO WATER INTERCOOLING}

Fig.4. shows the circuit of water cooled charge air cooler (WCAC). Here the coolant is water. The water is circulated through a circuit. This circuit consists of a radiator and a pump. The water after passing through radiator passes to water charge air cooler thereby removing heat from air. The present work is mainly focused on WCAC with same fin configurations, core size of the exchanger as charge air cooler (CAC). WCAC will have some advantages over charge air cooler (CAC).

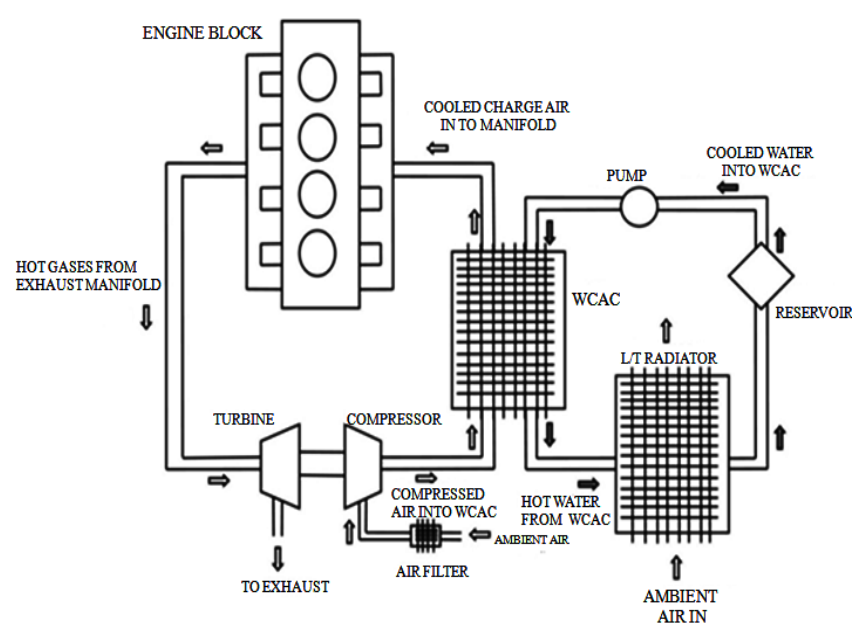

Fig-4: Water to Air charge air cooler circu it

\section{ANALYSIS OF PLATE FIN HEAT EXCHANGER}

The performance of a plate fin heat exchanger can be analyzed by putting the necessary equations in order as below:

Minimu $\mathrm{m}$ free flow area, $\left(\mathrm{A}_{\mathrm{o}}\right)$ is calcu lated as

$A_{\mathrm{o}}=(b-t) \times w \times(1-n t) \times N_{p}$

Where $b$ is plate spacing, $w$ is width of exchanger core, $N_{p}$ is no. of fluid passages, $\mathrm{n}$ is number of fins per unit length

Primary area of plate, $\left(A_{p}\right)$ is given by 
$\mathrm{A}_{\mathrm{p}}=2 \times\left\{l \times \mathrm{w} \times(1-\mathrm{nt}) \times \mathrm{N}_{\mathrm{p}}\right\}$

Secondary area or fin area, $\mathrm{A}_{f}$ is given by

$\mathrm{A}_{f}=2 \times(\mathrm{b}-\mathrm{t}) \times l \times \quad \mathrm{w} \times \mathrm{n} \times \mathrm{N}_{\mathrm{p}}$ (3)

Where $l$ is length of the exchanger core, $t$ is thickness of fin

Heat transfer area, A

$\mathrm{A}=2 \times\{$ primary area $\}+\mathrm{n}_{\mathrm{f}} \times$ secondary area

Hydraulic diameter, $\mathrm{D}_{\mathrm{h}}$

$\mathrm{D}_{\mathrm{h}}=\frac{2 \times(1-n t) \times(b-t)}{\{(1-n t)+n(b-t)\}}$

Heat given away by hot fluid is picked by cold fluid $\mathrm{Q}_{\mathrm{h}}=\mathrm{Q}_{\mathrm{c}}$

Temperature of the cold fluid, $\mathrm{t}_{\mathrm{co}}$ can calculated as

$$
\mathrm{t}_{\mathrm{co}}=\mathrm{t}_{\mathrm{ci}}+\frac{\mathrm{m}_{\mathrm{h}} \times \mathrm{C}_{\mathrm{ph}} \times(\text { thi }- \text { tho })}{\mathrm{m}_{\mathrm{c}} \times \mathrm{C}_{\mathrm{pc}}}
$$

Where, $t_{h i}, t_{h o}, t_{c i}$ and $t_{\mathrm{co}}$ are temperatures at inlet and outlet of hot and cold fluids respectively and $\mathrm{m}_{\mathrm{h}}, \mathrm{m}_{\mathrm{c}}$ are mass of hot and cold fluids respectively.

Core mass velocity $(\mathrm{G})$

$\mathrm{G}=\frac{\mathrm{m}}{\mathrm{A}_{\mathrm{o}}}$

Where $\mathrm{m}$ is mass flow rate of flu id

Reynolds number based on hydraulic diameter (Re)

$\operatorname{Re}=\frac{G \times D_{h}}{\mu}$

Where, $\mu$ is dynamic viscosity of fluid

The heat transfer and pressure drop correlations are expressed as $\mathrm{j}$ and $\mathrm{f}$ factors according to Shah and Dusan [1]

$$
\begin{aligned}
\mathrm{j}= & 0.6522 \times \operatorname{Re}^{-0.5403}(\alpha)^{-0.1541}(\delta)^{0.1499}(\gamma)^{-0.0678} \\
& \times\left[1+5.269 \times \mathrm{E}^{-5} \times \operatorname{Re}^{1.34}(\alpha)^{0.504}(\delta)^{0.456}(\gamma)^{-1.055}\right]^{0.1} \\
\mathrm{f}= & 9.6243 \times \operatorname{Re}^{-0.7422}(\alpha)^{-0.1856}(\delta)^{03053}(\gamma)^{-0.2659} \\
& \times\left[1+7.669 \times \mathrm{E}^{-8} \times \operatorname{Re}^{4.429}(\alpha)^{0.92}(\delta)^{3.767}(\gamma)^{0.236}\right]^{0.1}
\end{aligned}
$$

Where $\alpha, \delta, \gamma$ are constants expressed by

$$
\alpha=\frac{\mathrm{s}}{\mathrm{h}}, \delta=\frac{\mathrm{t}}{\mathrm{l}}, \gamma=\frac{\mathrm{t}}{\mathrm{s}}
$$

Where, $\mathrm{s}$ is fin spacing, $\mathrm{h}$ is fin height, $\mathrm{t}$ is fin thickness and $l$ is fin length.

Heat transfer coefficients for both the flu ids (h) accord ing to

Shah and Dusan [1]

$$
\mathrm{h}=\mathrm{j} \times \mathrm{G} \times \mathrm{C}_{\mathrm{p}} \times \mathrm{Pr}^{-2 / 3}
$$

Where, $C_{p}$ is specific heat of fluid and Pr refers to Prandtl number of fluid

Fin effectiveness can be calculated as

$$
\eta_{\mathrm{f}}=\frac{\tan h m l}{m l}
$$

Fin parameter for rectangular fin is given by

$$
m=\left(2 \mathrm{~h} / \mathrm{k}_{\mathrm{f}} \times \delta\right)^{1 / 2}
$$

(13)

Where, $l=(b / 2)-\delta$
Where, $\mathrm{h}$ refers to heat transfer coefficient, $\mathrm{k}_{\mathrm{f}}$ refers to thermal conductivity of fin material and $\delta$ refer to fin thickness

Overall surface effectiveness is given by

$$
\eta_{\mathrm{o}}=1-\left(1-\eta_{\mathrm{f}}\right) \frac{\mathrm{A}_{\mathrm{f}}}{\mathrm{A}}
$$

Where, $\mathrm{A}_{\mathrm{f}} / \mathrm{A}=$ fin area/heat transfer area

Overall heat transfer coefficient is determined by the equation,

$$
\frac{1}{\mathrm{UA}}=\frac{1}{\eta_{\mathrm{oh}}+\mathrm{A}_{\mathrm{h}}+\mathrm{h}_{\mathrm{h}}}+\frac{\mathrm{t}_{\mathrm{w}}}{\mathrm{k}_{\mathrm{w}}+\mathrm{A}_{\mathrm{w}}}+\frac{1}{\eta_{\mathrm{oc}}+\mathrm{A}_{\mathrm{c}}+\mathrm{h}_{\mathrm{c}}}
$$

Where, $\eta_{\text {oh }}$ and $\eta_{\text {oc }}$ are overall surface effectiveness on hot and cold fluid sides, $A_{h}$ and $A_{c}$ are heat transfer area on hot and cold flu id sides, $h_{h}$ and $h_{c}$ are heat transfer coefficient on hot and cold fluid sides, $\mathrm{k}_{\mathrm{w}}$ refers to thermal conductivity of wall, $\mathrm{t}_{\mathrm{w}}$ refers to thickness of wall.

$\mathrm{A}_{\mathrm{w}}$ refers to wall lateral conduction area given by

Where, $\mathrm{A}_{\mathrm{w}}=l \times \mathrm{w} \times\left(2 \mathrm{~N}_{\mathrm{p}}+2\right)$

From the known $U A$, NTU is determined as

$\mathrm{NTU}=\frac{\mathrm{UA}}{\mathrm{C}_{\min }}$

For unmixed -unmixed cross flow arrangement, $\varepsilon$ is given by

$\boldsymbol{\varepsilon}=1-\exp \left[\left(\frac{1}{c *}\right) \mathrm{NTU}^{0.22}\left\{\exp \left(-\mathrm{C}^{*} \mathrm{NTU}^{0.78}\right)-1\right\}\right.$

(18)

Where

$C^{*}=\mathrm{C}_{\min } / \mathrm{C}_{\max }$

\section{RESULTS AND DISCUSSION}

The values got from the above are shown plotted as graphs depicting their behavior as mentioned below.

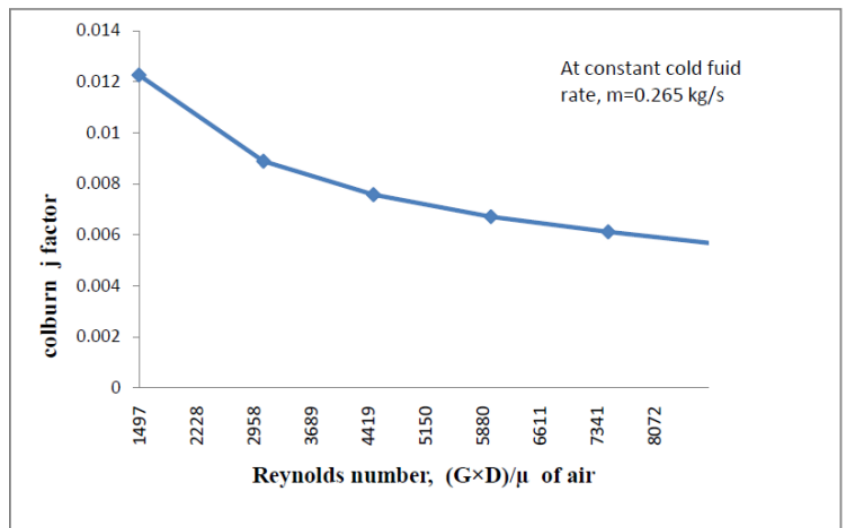

Fig-5: Effect of Colburn- $\mathrm{j}$ factor with Reynolds number of air

Fig.5. above shows the plot between Colburn $\mathrm{j}$ - factor and Reynolds number of air. It is seen from the graph that as Reynolds number increases, Colburn $\mathrm{j}$-factor decreases. 


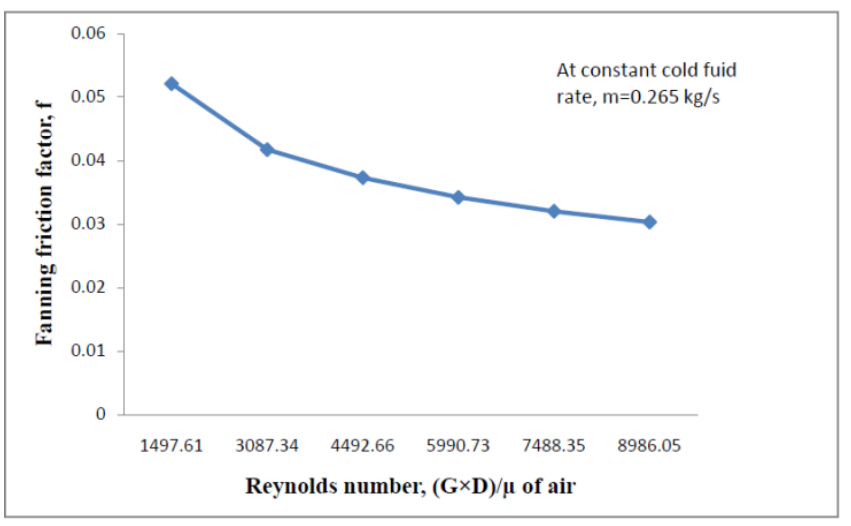

Fig- 6: Fanning friction factor for air

Fig.6. shows that the friction factor $f$, decreased with increase in Reynolds number of a charge air cooler with OSF. Friction factor gives high value in laminar zone Re < 2000 and decreases in turbulent zone. Friction factor depends on fin geometry with increase in fin geometry like height, length the friction factor tends to decrease.

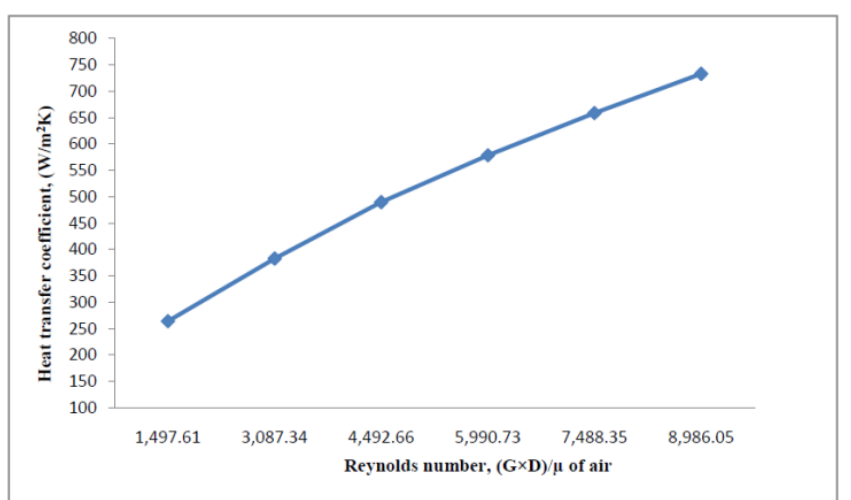

Fig-7: Heat transfer coeffic ient with Reynolds number of air

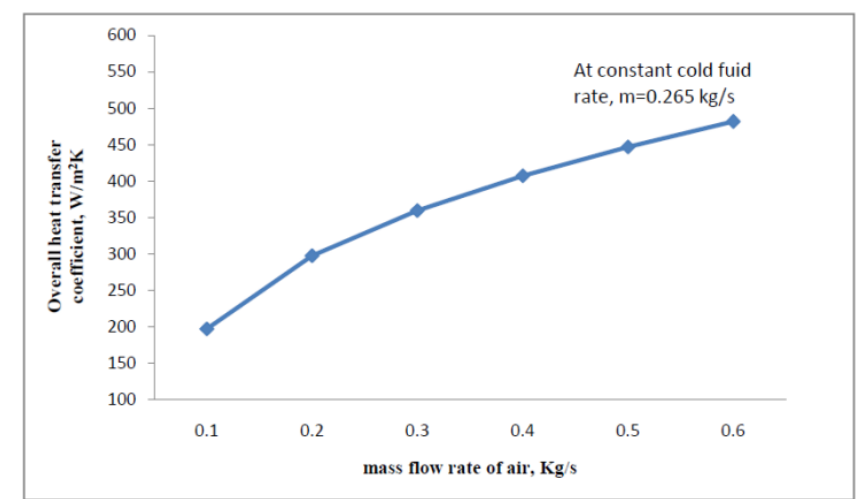

Fig-8: Variation of overall heat transfer coefficient with mass flow rate of air.

Fig.7. above shows the graph plotted between heat transfer coefficient and Reynolds number of air. As the offset strip fin length is small, the boundary layer in the form of laminar is developed and thus helps to increase in the value of heat transfer coefficient.

Fig. 8. above shows the variation of overall heat transfer coefficient with mass flow rate of air. The overall heat transfer depends on heat transfer coeffic ients of both hot and cold fluids side and surface areas. Generally heat transfer coefficient is small on air side. With the increase in mass flow rate of air, the Nusselt number increases, resulting in higher heat transfer coefficients. So with increased in mass flow rate of air from 0.1 to $0.6 \mathrm{~kg} / \mathrm{s}$ the heat transfer coefficients increases, resulting in increase of overall heat transfer coeffic ient.

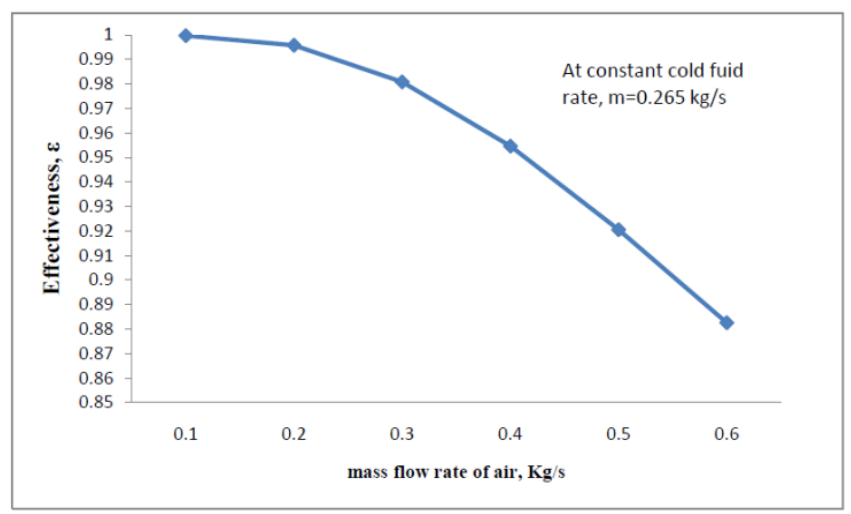

Fig-9: Variation of effectiveness with mass flow rate of air

Fig.9. shows that as mass flow rate increases, effectiveness of the water charge air cooler treated to be a heat exchanger decreases. It was found from the graph that for an increase in mass flow rate of air from 0.2 to $0.6 \mathrm{~kg} / \mathrm{s}$, effectiveness rapidly decreases.

\section{CONCLUSIONS}

1. A detailed procedure was given for estimating the areas and effectiveness of the water charge air cooler treating it as plate fin heat exchanger.

2. Taking same fin configuration, core size and temperature inlets of hot and cold fluid, it was found that watercooled charge air cooler gave higher effectiveness than air-cooled charge air cooler.

3. Varying hot fluid (air) mass flow rate from 0.1 to 0.6 $\mathrm{kg} / \mathrm{s}$ and keeping cold fluid (water) rate constant at 0.265 $\mathrm{kg} / \mathrm{s}$, with inlet temperatures taken on hot side as $160{ }^{\circ} \mathrm{C}$ and cold side as $40{ }^{\circ} \mathrm{C}$, the thermal performance of the exchanger was analyzed using $\varepsilon$-NTU method and results obtained are Colburn-j factor on air side was decreased by $58.79 \%$, friction factor on air side was decreased by $41.81 \%$, heat transfer coefficient increases by $177.46 \%$, overall heat transfer coefficient was enhanced by $115 \%$ and effectiveness of the exchanger was decreased by $22.36 \%$.

\section{NOMENCLATURE}

A heat transfer area, $\mathrm{m}^{2}$

b space between two plates in exchanger, $m$

C specific heat of fluid at constant pressure, $\mathrm{J} / \mathrm{kg}-\mathrm{K}$

$\mathrm{D}_{\mathrm{h}} \quad$ hydraulic diameter of flow passages, $\mathrm{m}$

$f \quad$ fanning friction factor

G mass velocity, $\mathrm{kg} / \mathrm{m}^{2}-\mathrm{s}$

h heat transfer coefficient, $\mathrm{W} / \mathrm{m}^{2}-\mathrm{K}$

j Colburn j-factor, St $\operatorname{Pr}^{2 / 3}$

$\mathrm{k} \quad$ fluid thermal conductivity, W/m.K 
L core length of the exchanger, $m$

$\mathrm{L}_{\mathrm{f}} \quad$ fin flow length on one side of a exchanger, $\mathrm{m}$

$l \quad$ fin height, $\mathrm{m}$

$l s \quad$ strip length of an offset strip fin, $m$

$m \quad$ fin parameter, $1 / \mathrm{m}$

$\mathrm{m} \quad$ fluid mass flow rate, $\mathrm{kg} / \mathrm{s}$

$\mathrm{Np} \quad$ number of fluid passages

NTU number of heat transfer units

$\mathrm{Nu} \quad$ Nusselt number

$\mathrm{n} \quad$ no of fins per length in the fin pitch direction, $1 / \mathrm{m}$

$\mathrm{P} \quad$ wetted perimeter of exchanger passages, $m$

Pr Prandtl number

$\mathrm{p} \quad$ flu id static pressure, $\mathrm{Pa}$

Q heat transfer rate, $\mathrm{W}$

Re Reynolds number

$\mathrm{s} \quad$ spacing between adjacent fins, $\mathrm{m}$

T temperature, ${ }^{\circ} \mathrm{C}$

$\mathrm{t}$ fin thickness, $\mathrm{m}$

$\mathrm{U} \quad$ overall heat transfer coeffic ient, $\mathrm{W} / \mathrm{m}^{2}-\mathrm{K}$

$\mathrm{u} \quad$ flu id mean axial velocity, $\mathrm{m} / \mathrm{s}$

$\mathrm{V}$ heat exchanger volu me, $\mathrm{m}^{3}$

\section{Greek symbols}

$\beta \quad$ heat transfer surface area density $\mathrm{m}^{2} / \mathrm{m}^{3}$

$\delta \quad$ fin thickness, $m$

$\varepsilon \quad$ heat exchanger effectiveness

$\eta_{f} \quad$ fin efficiency, dimensionless

$\eta_{o} \quad$ extended surface efficiency or overall efficiency

$\mu \quad$ flu id dynamic viscosity, $\mathrm{Pa}$-S

$v \quad$ kine matic viscosity, $\mathrm{m}^{2} / \mathrm{s}$

$\rho \quad$ fluid density, $\mathrm{kg} / \mathrm{m}^{3}$

\section{Subscripts}

c cold fluid side

f fin

fr frontal

h hot fluid side

i inlet

$\mathrm{m}$ mean bulk te mperature

o overall

$\mathrm{p} \quad$ primary

w wall

\section{REFERENCES}

[1] Ramesh K.shah and P.DusanSekulic, Fundamentals of Heat exchanger Design, John Wiley and Sons, 2003

[2] R.M.Manglik and A.E.Bergles, Heat Transfer and Pressure drop Correlations for Rectangular Offset Strip Fin Compact Heat Exchanger, Experimental Thermal and Fluid Science, Vol.10, pp.171-180, 1995.

[3] W.M.Kays and A.L.London, Compact Heat Exchangers. $2^{\text {nd }}$ Edition, Mc Graw-Hill, New York, 1964.

[4] L.W.Zhang, S.Balachandar, D.K.Tafti and F.M.Najjar, Heat Transfer Enhancement Mechanisms in Inline and Staggered Parallel Plate Fin Heat Exchanger, International Journal of Heat and Mass Transfer, Vol. 40, No.10, pp. 2307-2325, 1997

[5] N.C.Dejong, L.W.Zhang, A.M.Jacobi, S.Balchandar and D.K.Tafti, A Complementary Experimental and Numerical Study of Flow and Heat Transfer in Offset
Strip Fin Heat Exchangers, Journal of Heat Transfer, Vol.12, pp. 690-702, 1998

[6] H.Bhowmik and Lee, Analysis of Heat Transfer and Pressure Drop Characteristics in an Offset Strip Fin Heat Exchanger, International Journal of Heat and Mass Transfer, Vol.36, pp.259-263, 2009

[7] S.Hu and K.E.Herold, Prandtl Number Effect on Offset Strip Fin Heat Exchanger Performance: Pred ictive Model for Heat Transfer and Pressure Drop, International Journal of Heat and Mass Transfer, Vol. 38, No.6, pp. 1043-1051, 1995

[8] J.N. Devi sankar, Performance Analysis of Charge Air Cooler in Turbo Charged Diesel Engine, M.E. Thesis, Andhra University, 2016

[9] Hao Peng, Xiang Ling and Juan Li, Performance Investigation of an Innovative Offset Strip Fin Arrays in Compact Heat Exchangers, Energy Conversion and Management, Vol.80, pp.287-297, 2014

[10] Kupeng Guo, Zhang and Robin Smith, Optimization of Fin Selection and Thermal Design of Counter-Current Plate-Fin Heat Exchangers, Applied Thermal Engineering, Vol.78, pp. 491-499, 2015

[11] Incropera and David.P.DeWitt, Fundamentals of Heat and Mass Transfer, John Wiley and Sons, 2012. 